\title{
Multi-year investigations of aerosols from an island station, Port Blair, in the Bay of Bengal: climatology and source impacts
}

\author{
S. Naseema Beegum ${ }^{1}$, K. Krishna Moorthy ${ }^{2}$, Mukunda M. Gogoi ${ }^{2}$, S. Suresh Babu ${ }^{2}$, and S. K. Pandey \\ ${ }^{1}$ National Physical Laboratory, CSIR, New Delhi - 110 012, India \\ ${ }^{2}$ Space Physics Laboratory, VSSC, Thiruvananthapuram - 695022, India \\ ${ }^{3}$ ISTRAC ground station, Dolly Gunj, Port Blair - 744 101, India
}

Correspondence to: K. Krishna Moorthy (krishnamoothy_k@vssc.gov.in)

Received: 3 April 2012 - Revised: 26 June 2012 - Accepted: 3 July 2012 - Published: 8 August 2012

\begin{abstract}
Long-term measurements of spectral aerosol optical depth (AOD) using multi-wavelength solar radiometer (MWR) for a period of seven years (from 2002 to 2008) from the island location, Port Blair $\left(11.63^{\circ} \mathrm{N}, 92.7^{\circ} \mathrm{E}, \mathrm{PBR}\right)$ in the Bay of Bengal (BoB), along with the concurrent measurements of the size distribution of near-surface aerosols, have been analyzed to delineate the climatological features of aerosols over eastern BoB. In order to identity the contribution of different aerosol types from distinct sources, concentration weighted trajectory (CWT) analysis has been employed. Climatologically, AODs increase from January to reach peak value of $\sim 0.4$ (at $500 \mathrm{~nm}$ ) in March, followed by a weak decrease towards May. Over this general pattern, significant modulations of intra-seasonal time scales, caused by the changes in the relative strength of distinctively different sources, are noticed. The derivative $\left(\alpha^{\prime}\right)$ of the Angstrom wavelength exponent $\alpha$ in the wavelength domain, along with CWT analysis, are used to delineate the different important aerosol types that influence this remote island. Corresponding changes in the aerosol size distributions are inferred from the numerical inversion of the spectral AODs as well from (surface) measurements. The analyses revealed that advection plays a major role in modifying the aerosol properties over the remote island location, the potential sources contributing to the accumulation mode (coarse mode) aerosols over eastern BoB being the East Asia and South China regions (Indian mainland and the oceanic regions).
\end{abstract}

Keywords. Atmospheric composition and structure (Aerosols and particles)

\section{Introduction}

Long-term measurements of aerosol characteristics from small islands located in far oceanic regions, yet under the influence of densely populated and industrialized diverse continental landmass, provide an effective means to delineate the impacts from different source regions, aided by favorable airmass types in perturbing the rather pristine oceanic environments through long-range transport (Prospero et al., 1983; Andreae, 1995; Moorthy and Satheesh, 2000; Moorthy and Saha, 2000; Kamra et al., 2001; Li and Ramanathan, 2002; Moorthy et al., 2003). Such effects also facilitate in quantifying the roles of different aerosol types dominated by natural and/or anthropogenic species, depending on the characteristics of the impacting source regions. The multifarious impacts on climate, coupled with the lack of adequate understanding on the spatio-temporal distribution of the physical and optical properties, make atmospheric aerosols one of the least understood forcing agents of the Earth's climate. Regional climatological aerosol models, depicting the distinct seasonal features, are essential in reducing the uncertainties in the forcing estimates. While the natural aerosols have a major share in global-scale climate forcing due to their distinct dominance (Satheesh and Moorthy, 2005) and are not amenable to mitigation, the anthropogenic aerosols produce significant regional impacts, depending on the source strength and meteorology. As such, it is essential to delineate the effects of natural and anthropogenic aerosols (ElMetwally et al., 2008) and the island observations are quite suited for this purpose.

Several recent research works have indicated that the aerosols over the Indian landmass as well as over the 
adjoining oceanic regions are likely to have significant roles in the Indian monsoon as well as on the global climate (Ramanathan et al., 2001; Ramanathan et al., 2005; Menon et al., 2002; Chung et al., 2005; Lau et al., 2006; Moorthy et al., 2009). Several field experiments have also been carried out to characterize the aerosols over the South Asian region (landmass and oceans) such as Indian Ocean Experiment (INDOEX) (Ramanathan et al., 2001), the Arabian Sea Monsoon Experiment (ARMEX-I and ARMEX-II) (Vinoj and Satheesh, 2003; Moorthy et al., 2005), Aerosol Characterization Experiment over Asia (ACE Asia, Huebert et al., 2003), Integrated Campaign for Aerosols, gases and Radiation Budget (ICARB and W_ICARB) (Moorthy et al., 2008, 2009, 2010; Satheesh et al., 2008; Beegum et al., 2009; Nair et al., 2008, 2009). Notwithstanding the large number of new findings, all these campaigns have been limited in their temporal coverage, the longest of these being the ICARB and as such, providing only a short sample that is subjected to temporal variations associated with the synoptic and meteorological variables (Beegum et al., 2008). The only exception to this has been the all-season characterization of aerosols in the southeastern Arabian Sea by Satheesh and Moorthy (2000) and Vinoj et al. (2010) based on extensive multi-year data from the island station Minicoy. Such an attempt, however, does not exist for the Bay of Bengal (BoB), a rather small oceanic region surrounded on more than three sides by densely populated continental landmass, having diverse anthropogenic activities and complex natural features. A few reports, available based on the measurements from this region, are mostly season-specific or species specific (Moorthy et al., 2003; Moorthy and Babu, 2006) and mostly serve as case studies. Even though a few papers have appeared recently based on extensive cruise measurements over the oceanic region of Bay of Bengal, they are limited to a given season of the year, and covered a very large oceanic region with embedded heterogeneity. Consequently, the spatial variation gets coupled with the temporal variations. The inferences drawn from those papers (Moorthy et al., 2008, 2009, 2010; Kumar et al., 2010; Kaskaoutis et al., 2011; Kharol et al., 2011; Srinivas et al., 2011; Babu et al., 2012), though suggestive and valuable in themselves, suffer from the above limitation. In the present study, we examine 7-year of continuous data (constrained by the weather conditions) from a fixed location, and as such offer insights into the climatological features of aerosols which are useful inputs to regional aerosol models. This paper examines the optical and microphysical properties of the $\mathrm{BoB}$ aerosols using long-term (seven years) continuous data obtained from the island station Port Blair (PBR, $11.63^{\circ} \mathrm{N}, 92.7^{\circ} \mathrm{E}, 73 \mathrm{~m}$ a.m.s.l. - altitude above mean sea level) situated in the eastern BoB. From the spectral AOD and near-surface size distribution data, in conjunction with the back trajectory and CWT analyses, we delineate the changes in the climatological features caused by dominant aerosol types associated with distinct continental source regions.

\section{Observational data}

Continuous measurements of columnar spectral aerosol optical depths (AOD) and near-surface mass size distribution (MSD) were carried out from the island location Port Blair (PBR), the administrative capital of the Andaman and Nicobar group of islands, a long chain of islands spread from $6^{\circ} \mathrm{N}$ to $14^{\circ} \mathrm{N}$ and $92^{\circ} \mathrm{E}$ to $94^{\circ} \mathrm{E}$ in the eastern BoB. The experimental data comprised of columnar spectral AOD at 10 narrow wavelength bands (from near-UV to near-IR, estimated using a multi-wavelength solar radiometer (MWR, Moorthy et al., 2007; Kompalli et al., 2010) along with the total as well as size-segregated mass concentration of ambient aerosols using a ten-channel quartz crystal microbalance (QCM) cascade impactor. The data collected for a period of seven years from January 2002 to December 2008 formed the database for these investigations.

Columnar spectral AODs were regularly estimated using the MWR at 10 wavelength bands centered at 380, 400, $450,500,600,650,750,850,935$, and $1025 \mathrm{~nm}$ selected using narrow band interference filters having full-width at half maximum (FWHM) bandwidths of 5 to $6 \mathrm{~nm}$ at different wavelengths. A 3-cavity configuration ensured a near uniform transmittance within the pass-band and a sharp reduction in the transmission beyond. The MWR had a field of view of $2^{\circ}$. Using this instrument, columnar measurements of spectral extinction of direct solar irradiance have been made from which the AODs were retrieved following Moorthy et al. (2007). More details of the instrument, method of analysis and error budget are given in several earlier papers (e.g. Moorthy et al., 2007; Gogoi et al., 2009), while Kompalli et al. (2010) have extensively inter-compared the AODs estimated using MWR with those estimated concurrently using other commercial sun-photometers with very good consistency. Effects of patchy clouds were removed by screening the data using a Student's t-test for a confidence coefficient of 0.99. The estimated spectral AODs corresponded to the daily mean or means for the forenoon and afternoon (FN and AN) parts of the same day, whenever the data spanned over $>3 \mathrm{~h}$ in the FN \& AN parts, or whenever the Langley plots showed a change in the slope from FN to AN. From these individual AOD spectra, the monthly means are estimated.

Concurrent measurements of the mass size distributions (MSD) of near-surface aerosols were made using a 10channel quartz crystal microbalance (QCM) cascade impactor. The impactor aspirated ambient air (from a height of $\sim 2 \mathrm{~m}$ above the ground level, at a flow rate of $240 \mathrm{ml} \mathrm{min}^{-1}$ ) and segregated the particles in accordance with the aerodynamic diameters into one of its ten size bins. It measured the mass concentration of the particles collected in each stage $\left(m_{\mathrm{ci}}\right)$ as a function of particle diameter assuming the particle density $(\rho)$ as $2 \mathrm{~g} \mathrm{~cm}^{-3}$ (Pillai and Moorthy, 2001). As such, it yielded mass concentration in ten size bins, the $50 \%$ lower cut-off diameter of which varied from 0.05 to $25 \mu \mathrm{m}$. Even though it directly gives the information about two parameters 
(the total mass concentration $\left(M_{\mathrm{T}}\right)$ and the mass concentrations in each size bins $\left.\left(m_{\mathrm{ci}}\right)\right)$, the parameters such as effective radius $\left(R_{\text {eff }}\right)$, mass-size distribution, number size distribution, etc. could be derived from these. More details of the instrumentation, analysis and error budget are given elsewhere (Pillai and Moorthy, 2001; Moorthy et al., 2003).

The Andaman-Nicobar island chain, located $\sim 1300 \mathrm{~km}$ off the east coast of Indian mainland is moderately inhabited ( $\sim 0.16$ million), with its administrative capital Port Blair (PBR) accounting for $\sim 45 \%$ of its population. The actual observation site has been on a hillock, $6 \mathrm{~km}$ south of the town center and the port, in the premises of ISTRAC (Indian Space Research Organization's Telemetry, Tracking and Command Network) at Dolly Gunj (Moorthy et al., 2003). While most of the human settlement is centered on the Andaman island chain north of $\sim 10^{\circ} \mathrm{N}$, the South Andaman and the Nicobar islands are characterized by dense forests and vast water bodies, creeks and bays. Thus, it provides a fairly good location for long-term monitoring of aerosols over BoB with considerably low contamination from the local anthropogenic activities.

\section{General meteorology}

The station experiences a typical tropical climate with extensive rainfall. The annual distribution of climatological mean monthly total rainfall is shown in Fig. 1. The distribution showed negligible rainfall during January, with a gradual increase reaching very high values by May when the station receives, on average, $\sim 500 \mathrm{~mm}$ rainfall. This persists until October with varying intensities, thereafter gradually decrease towards December. The average meteorological features revealed weak north-easterlies, relatively low relative humidity $(<80 \%)$ and weak rainfall (Fig. 1) from November to April, and strong south-westerlies accompanied by high relative humidity and extensive rainfall during May to September (Moorthy and Babu, 2006). As such, the study focuses on two seasons, winter monsoon (December through February, WMS) and pre-monsoon (March to May, PrMS). For the remaining two seasons of summer monsoon (June to September, SMS) and post monsoon (October and November, PoMS), the number of data points were less numerous because of adverse sky conditions associated with extensive monsoon rainfall (Fig. 1) and the prevailing very high ambient relative humidity, which are not favorable for the MWR and QCM measurements.

The climatological mean (2002 to 2008) synoptic wind vectors at $850 \mathrm{hPa}$ for the oceanic region, derived from NCEP data, are shown in Fig. 2 for the months from January to May. The measurement site is also marked in the figure by a black spot. During the months of January and February, the circulation associated with the low-level anticyclone prevailing over the Indian landmass drives continental aerosols from Indian landmass over to the head $\mathrm{BoB}\left(\geq 15^{\circ} \mathrm{N}\right)$ through

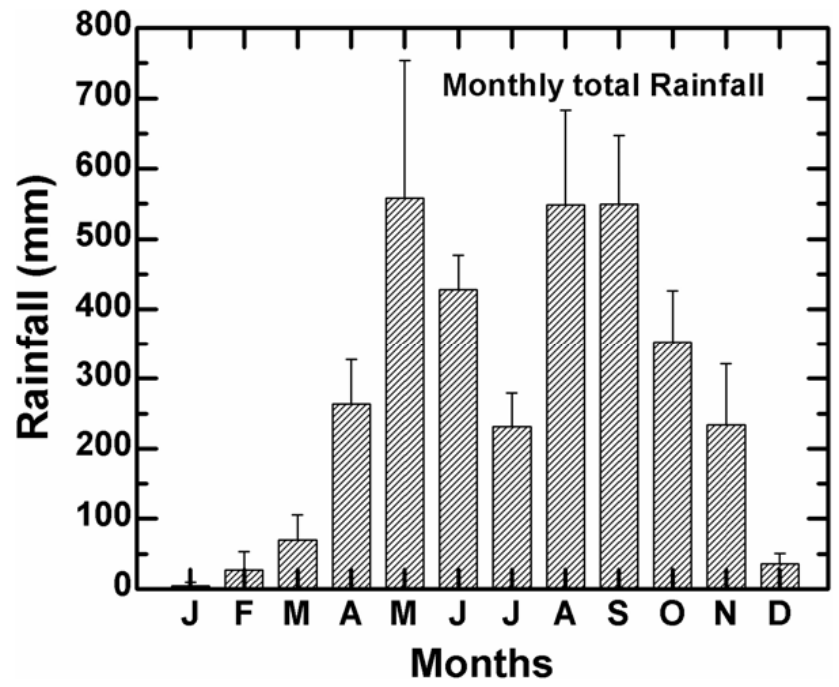

Fig. 1. The climatology of the monthly total rainfall averaged over the period 2002-2008 at Port Blair.

strong north-westerlies. Over mid and southern Bay of Bengal, the prevailing stronger easterlies facilitate advection of aerosols from East Asian region. Towards March, the anticyclonic circulation weakens and tends to shift towards the eastern coastal region. Even though the pattern of wind vectors over the entire oceanic region remain similar to the previous month, the magnitudes have reduced. During April, the prevailing winds are very weak over the entire oceanic region $\left(<3 \mathrm{~m} \mathrm{~s}^{-1}\right)$, with weak westerlies over the head BoB. Towards May, the pattern changes completely and strong westerlies/south-westerlies (wind speeds $\sim 10 \mathrm{~m} \mathrm{~s}^{-1}$ ) are established over the entire oceanic region. Over Port Blair, strong easterly winds of January change to south-westerlies in May. The observed pattern is in general conformity to the climatological pattern for the region (Asnani, 1993).

\section{Results and discussions}

\subsection{Climatology of columnar AOD}

The temporal variation of the climatological mean (averaged over the seven-year period) spectral AOD over PBR is shown in Fig. 3. The wide gap from June to October signifies the prevailing persistent cloudy and rainy conditions making the solar extinction measurements impossible. Considering the rest of the period, the climatological pattern revealed a gradual increase in AOD (at all wavelengths) from moderate values $(\sim 0.25$ at $500 \mathrm{~nm})$ in November to peak values $(\sim 0.4$ at $500 \mathrm{~nm}$ ) reached by March, followed by a small decrease. Even though the seasonal variation of AOD is more or less similar at other wavelengths, the variation in the spectral dependencies in AOD is not clear from Fig. 3. 

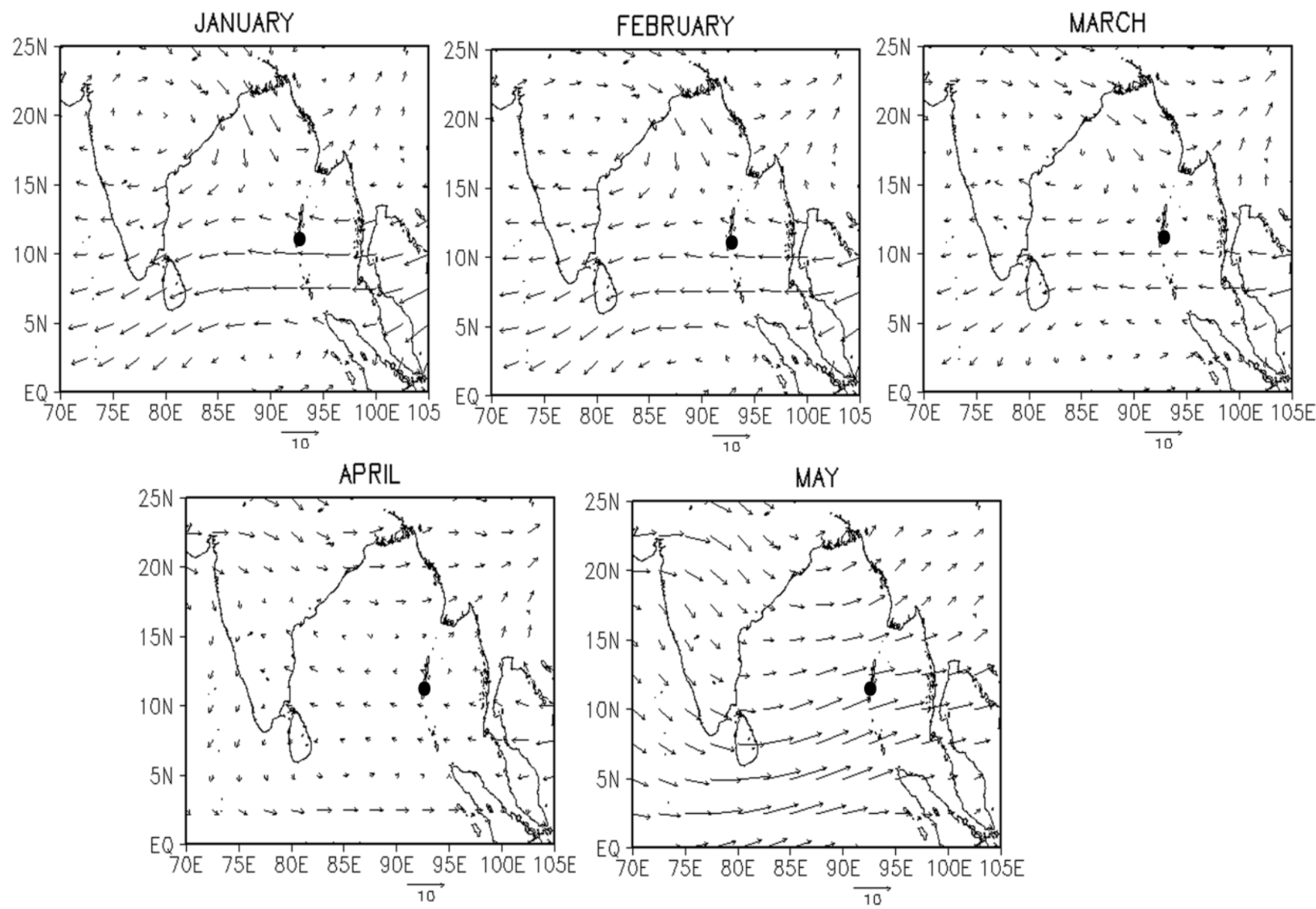

Fig. 2. The climatology of monthly mean, NCEP-derived winds over Bay of Bengal from January to May. The measurement site Port Blair is marked by the black dot in the figure.

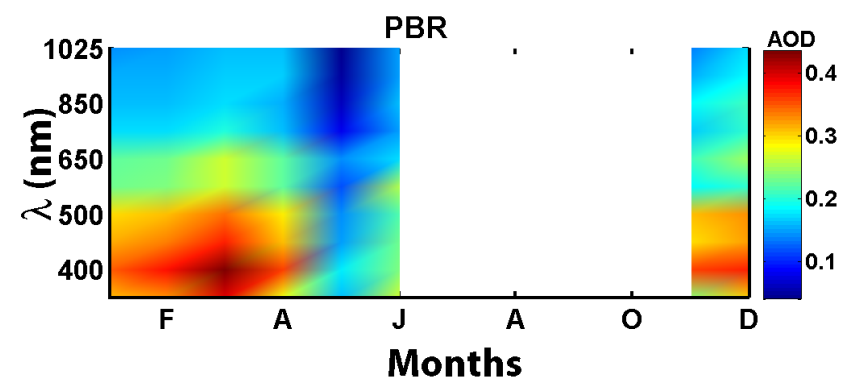

Fig. 3. The climatology of monthly mean spectral AOD (averaged over 2002-2008).

\subsection{Spectral AODs and their wavelength dependencies}

With a view to examining the annual and inter-annual variations in AODs and its spectral dependencies, monthly mean values have been estimated from the individual day's measurements of spectral AODs for the study period (20022008) and are shown in Fig. 4. The bar chart depicts the temporal variations of the monthly mean AODs at three wave- lengths of $380 \mathrm{~nm}, 500 \mathrm{~nm}$ and $1025 \mathrm{~nm}$ (at short and long wavelength ends, besides the mid visible) as representative. In general, AODs were found to vary from 0.15 to 0.4 at $500 \mathrm{~nm}$, with strong seasonal and weaker, yet significant, inter-annual variations. The AOD values remained low during winter months and increased towards the pre-monsoon season (March to May), the pattern being consistent over the years. Being a remote island with subdued human activities, the observed variation would be more associated with transport from other regions. A few recent studies have shown significant contribution of advected aerosols from source regions such as East Asia, eastern coastal India, central India and Arabian Sea, through organized pathways in modifying aerosol characteristics over BoB (Moorthy et al., 2003; Vinoj et al., 2004; Satheesh et al., 2006; Moorthy and Babu, 2006), with consequent signatures on the columnar spectral aerosol optical depth and concentration near the surface. Under such scenarios, it is imperative that the columnar aerosol content would be the resultant of the different aerosol types and would undergo seasonal/temporal changes associated with the advection pathways. This would lead to 


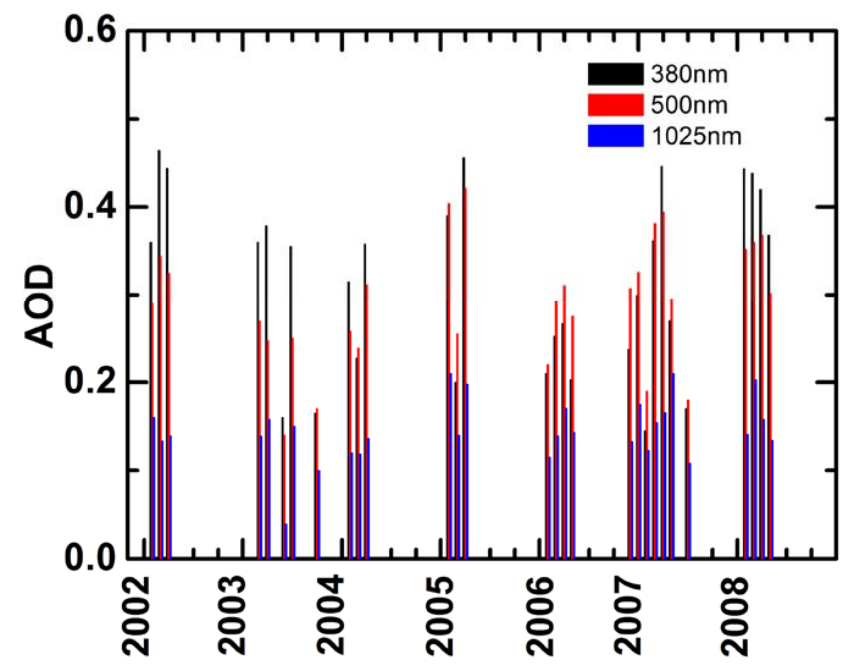

Fig. 4. Time series of the monthly mean AOD at three wavelengths ( $380 \mathrm{~nm}, 500 \mathrm{~nm}$ and $1025 \mathrm{~nm}$ ) from year 2002 to 2008 .

the spectral variation of AOD to deviate considerably from the simple Angstrom relation,

$\tau_{p \lambda}=\beta \lambda^{-\alpha}$

where $\tau_{p \lambda}$ and $\beta$ are the spectral AOD and turbidity coefficient, respectively, and depict curvature in wavelength domain (Moorthy et al., 1991; Saha et al., 2005; Kaskaoutis et al., 2006; Beegum et al., 2009). This feature of the AOD spectra has been utilized to infer on the dominant aerosol types (e.g. Eck et al., 1999; O'Neill et al., 2001a, b, 2002, 2003; Kaskaoutis et al., 2006; Kaskaoutis and Kambezidis, 2006; Beegum et al., 2009).

Following the above, and expressing the AOD- $\lambda$ relationship using a second order polynomial (King and Byrne, 1976; Eck et al., 1999, 2001; Reid et al., 1999; Schuster et al., 2006) of the form

$\ln \tau_{p \lambda}=a_{2}(\ln \lambda)^{2}+a_{1} \ln \lambda+a_{0}$

where $a_{0}, a_{1}$ and $a_{2}$ are coefficients, with the coefficient $a_{2}$ accounting for the "curvature", and taking the first and second derivatives of the Eq. (2), with respect to $\lambda$ we get

$\frac{d \ln \tau_{p \lambda}}{d \ln \lambda}=2 a_{2} \ln \lambda+a_{1}$

and

$\frac{d^{2} \ln \tau_{p \lambda}}{d(\ln \lambda)^{2}}=-\frac{d \alpha}{d \ln \lambda}=2 a_{2}$

where the derivative of $\alpha$ is

$\alpha^{\prime}=\frac{d \alpha}{d \ln \lambda}=-2 a_{2}$.

The examination of the spectral AODs revealed that the basic shapes of the AOD spectra show contrasting features even within a season or month itself; with a rapid decrease in AOD with $\lambda$, resulting in a convex spectral curvature at times and a much slower decrease with $\lambda$ followed by a weak increase in AOD at longer wavelengths, resulting in a concave spectral curvature (as illustrated in Fig. 5) on several other occasions. The dotted lines in Fig. 5 represent the regression fit of the measurement to the first order Angstrom formula (Eq. 1), while the solid lines represent the regression fit to the second order polynomial relation given by the Eq. (2). The corresponding squared correlation coefficients, $\left(R^{2}\right)$ are also given in the respective panels separately for winter and premonsoon seasons (the seasons for which the database were strong). It is interesting to note that for both the cases, irrespective of the seasons, the measured AODs fit better to the second order polynomial than to the simple Angstrom relation, as evident from the correlation coefficients.

At this juncture, a brief description on the errors and uncertainties on the computation of the derivative of the Angstrom exponent is necessary. Even though the second-order polynomial fit to $\ln \tau$ versus $\ln \lambda$ has been shown to provide good agreement with measured AODs, in comparison with the simple first order Angstrom fit, this approach is not always valid, especially over pristine oceanic regions with relatively low AODs $(<0.2)$. In such cases, the estimated errors in the coefficients of $a_{1}$ and $a_{2}$ (Eq. 2) are high (Eck et al., 1999, 2001; Kaskaoutis et al., 2010). However, as AOD increases (AOD $>0.3$ at $500 \mathrm{~nm}$ ), a drastic decrease in the errors are observed (Kaskaoutis et al., 2010). In the present study, the measured AODs at $500 \mathrm{~nm}$ were in between 0.3 to 0.8 and hence the computed values of errors in $a_{1}$ and $a_{2}$ remained low and were comparable or lower than the magnitude of AOD. Thus, the observed curvatures in the spectral AODs are significant.

While $\alpha$ is an indicator of the size distribution of aerosols, its derivative, $\alpha^{\prime}$ impart a clearer picture of the possible type of aerosols and in turn the potential sources also. The sign of $\alpha^{\prime}$ in Eq. (5) depends on the nature of the curvature of the AOD spectra, with the positive (negative) values of $\alpha^{\prime}$ depicting a convex (concave) curvature. The positive values of $\alpha^{\prime}$ signify fine/accumulation mode-dominated aerosol size distributions (and as such considered mainly of anthropogenic, biomass burning, urban and industrial origin). On the other hand, negative values of $\alpha^{\prime}$ are characteristic of size distributions with a significant coarse mode or bimodal distributions, with a strong coarse mode typically attributed to mineral dust or sea salt (Eck et al., 1999; O'Neill et al., 2001b; Kaskaoutis et al., 2006; Beegum et al., 2009).

Examining the daily mean spectral AODs in the light of the above, it has been found that $\alpha^{\prime}$ (Fig. 6, bottom panel) varied between highly positive and negative values in short time scales, even within a month, while the $\alpha$ values are found to vary from near zero values to as high as 2 , as shown in Fig. 6 (top panel). In general, the lower values of $\alpha(\alpha \leq 1)$ indicate aerosol size distributions dominated by coarse mode aerosols, while the values of $\alpha \geq 2$ depict 


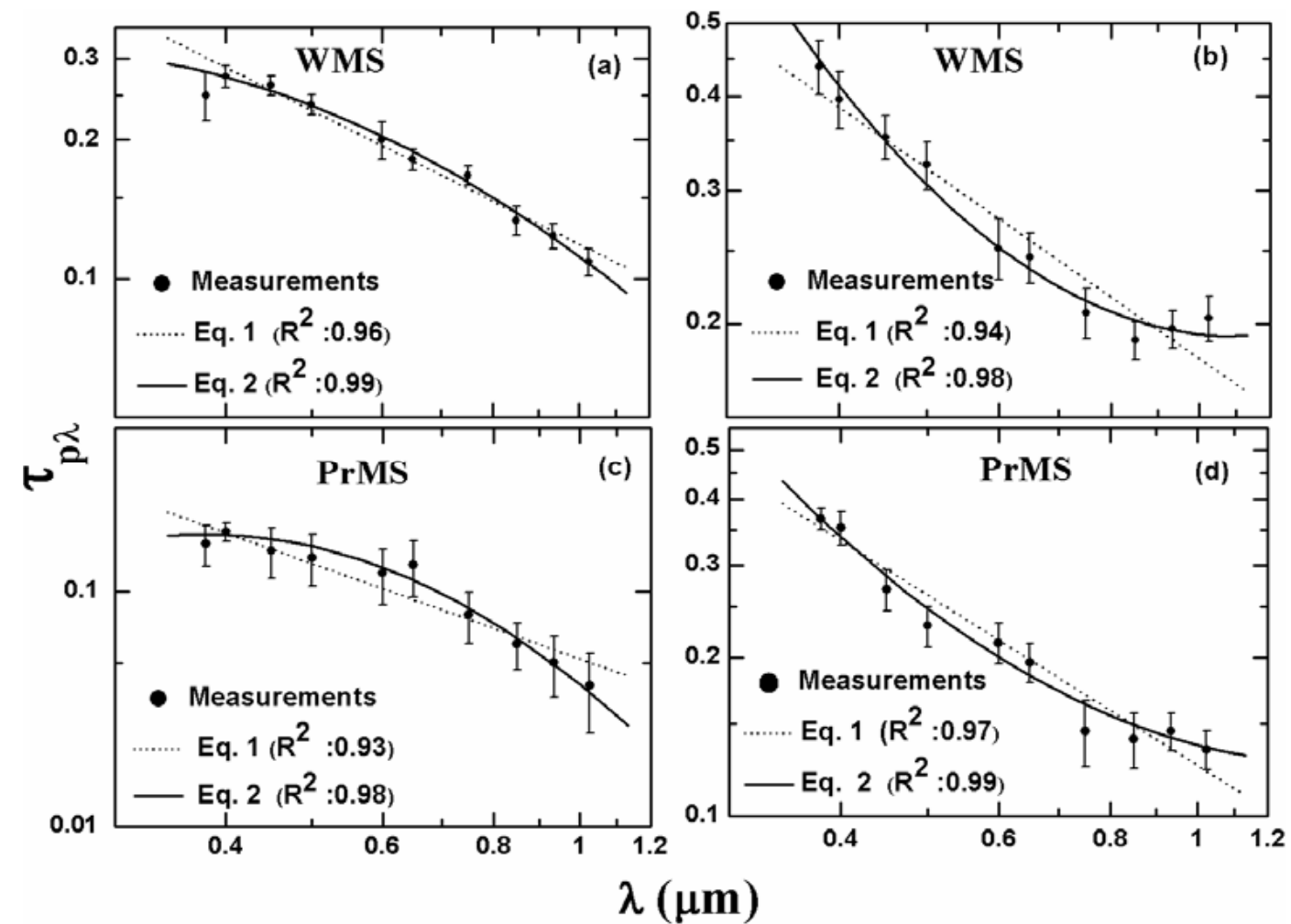

Fig. 5. Average AOD spectra over PBR for the two cases of contrasting spectral curvature for both the seasons of WMS and PrMS for the period 2002 to 2008. The filled circles are the mean AODs and the vertical bars, the standard deviations. The dotted line represents the linear fit of AOD, according to the simple Angstrom relation (Eq. 1) and the solid line represents the second order polynomial fit (Eq. 2).

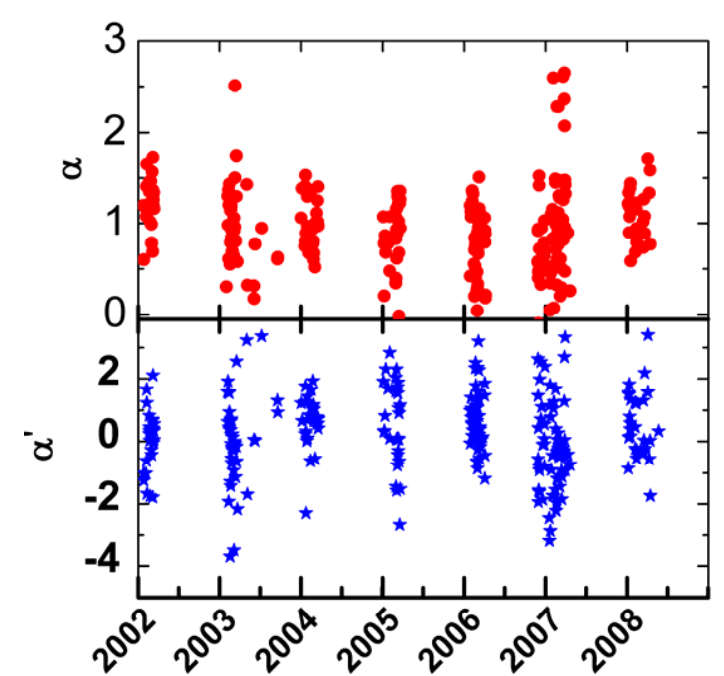

Fig. 6. Time-series of the daily mean values of the simple Angstrom exponent, $\alpha$ (top panel) along with the corresponding derivatives, $\alpha^{\prime}$ (bottom panel), estimated from the daily mean spectral AODs from 2002 to 2008.

aerosol columnar size distributions dominated by fine mode aerosols $(r<1 \mu \mathrm{m})$, such as from biomass burning or urban/industrial activities (Holben et al., 1991; Westphal and
Toon, 1991; Kaufman et al., 1992; Reid et al., 1999; Eck et al., 1999), and $1.0<\alpha<2$ suggest the prevalence of mixed type of aerosols with significant contributions from both accumulation mode and coarse mode aerosols to the columnar AOD. The top panel of Fig. 6 clearly indicates that the number of occurrences of $\alpha$ values in between 1 and 2 is quite substantial ( $\sim 45 \%$ of the total). At the same time, significantly high magnitudes of $\alpha^{\prime}$ (-3 to 3 ) exemplify the spectral curvatures. This implies that, even though the aerosols prevailing at the site are of mixed type arising from two or more distinctively different sources (either natural or anthropogenic), the relative dominance of these vary rather rapidly. The high scatter of points with poor correlation coefficient $(\sim 0.12)$ between $\alpha$ and $\alpha^{\prime}$ (in Fig. 7) clearly demonstrates this. Existence of such conditions with contrasting values of $\alpha^{\prime}$ for particular values of $\alpha$, especially during the transitions seasons with the prevalence of multiple sources, has been reported earlier also (e.g. Beegum et al., 2009). However, it is possible to discriminate between different aerosol types from the scatter plot. Coarse mode-dominated size distribution can be distinguished by the negative $\alpha^{\prime}$ values, while the biomass burning and the urban aerosols by the positive values. But, within the interval of $0.5-1.5$ for $\alpha$, urban aerosols can exhibit both positive and negative $\alpha^{\prime}$ values, as they have bimodal distributions with significant coarse fraction due 


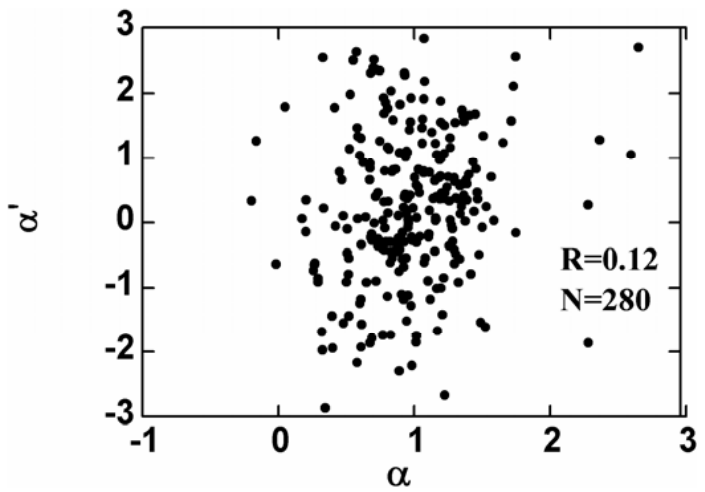

Fig. 7. Scatter plot showing the association between the derivative of the Angstrom exponent $\alpha^{\prime}$ and Angstrom exponent $\alpha$.

to coagulation, condensation, gas-to-particle conversion and humidification processes (e.g. Eck et al., 2005; Gobbi et al., 2007; Kaskaoutis et al., 2007). As a consequence, for lower $\alpha$ values the curvature can be positive or negative, exhibiting larger scatter as shown in the figure. From Mie calculations, Schuster et al. (2006) have indicated that the increase in the concentrations of coarse-mode particles reduces $\alpha$ values and dampens its sensitivity to the fine-mode effective radius.

As the measurement location is less influenced by the proximity to any rapidly varying local sources, the observed changes in types of aerosols might have occurred by advection from far-off source regions. As such, concurrent meteorological parameters which favor long-range transport have been examined. The time-series of prevailing zonal $(U)$ and meridional $(V)$ components of NCEP-derived daily mean wind vectors for the period of study at $850 \mathrm{hPa}$ are shown in the middle and top panels of Fig. 8, along with the corresponding $\alpha^{\prime}$ values. Both components depict rapid fluctuations (both in magnitude and direction), and the fluctuations are found to be similar to those observed for $\alpha^{\prime}$. Another important observation is that the positive values of $\alpha^{\prime}$ are closely associated with easterlies $(U<0)$ and the negative values are correlated with the corresponding westerlies $(U>0)$. Further, the magnitudes of the derivatives of the Angstrom exponent are well-related to the amplitudes of the winds (either easterlies or westerlies). Such a one-to-one correlation is lacking in the meridional component. This implies that the values of $\alpha^{\prime}$ remain positive whenever the prevailing winds at the measurement location are south-easterlies or northeasterlies. These winds favor advection of fine/accumulation mode aerosols from the anthropogenic aerosol-laden eastern continental locations, while the westerlies would bring significant coarse mode natural aerosols either from the Indian subcontinent and/or from the vast oceanic regions to the west of the measurement location. Thus, it is clear that the alternating easterlies and westerlies facilitate subsequent changes in the potential advection pathways, and which in turn result
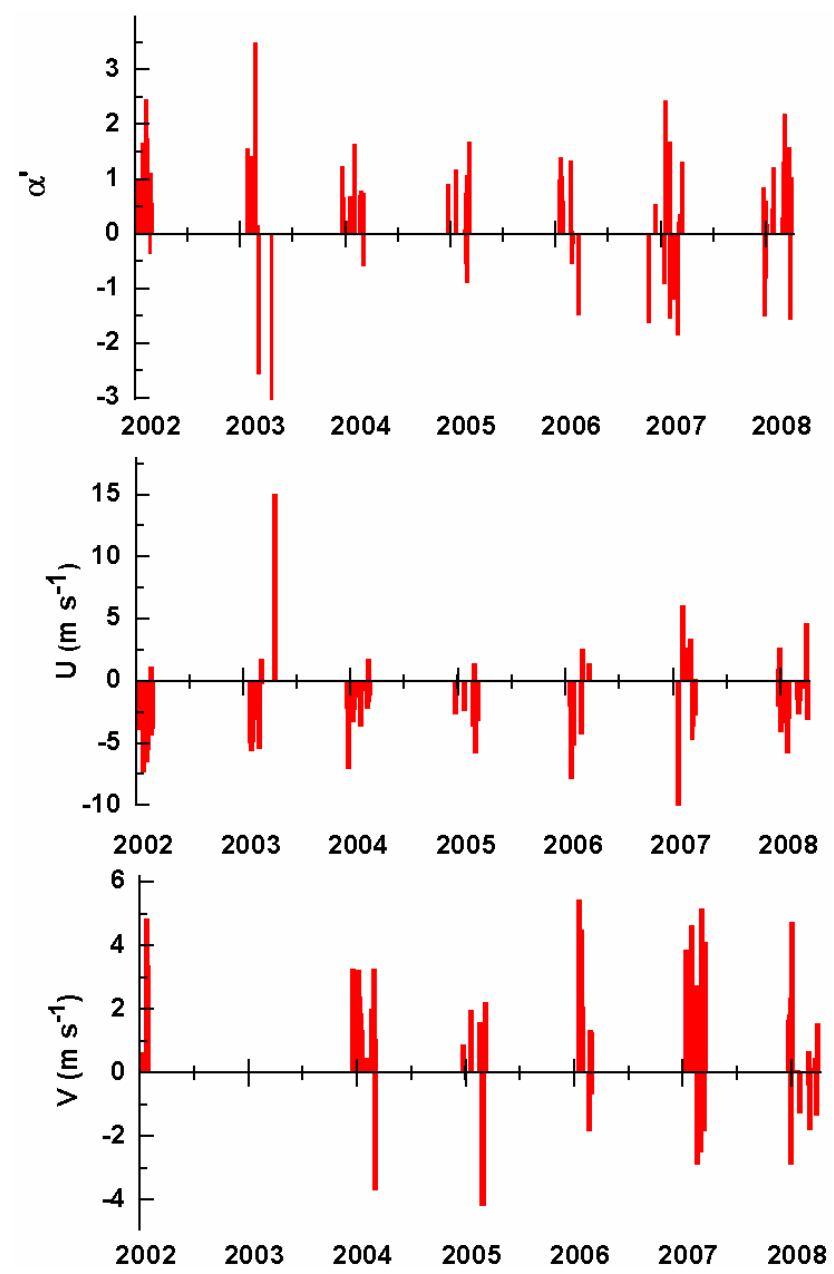

Fig. 8. Time series of the daily mean values of zonal $(U)$ and meridional $(V)$ components of the NCEP-derived winds at $850 \mathrm{hPa}$ at Port Blair during the days of MWR measurements along with the corresponding derivatives of the Angstrom exponent $\alpha^{\prime}$.

in rather rapid fluctuations in the aerosol types at the remote location.

In the backdrop of the above findings, the columnar size distributions of aerosols are examined by numerically inverting the AOD spectra.

\subsection{Size distributions inferred from spectral AODs}

Columnar size distributions (CSD) were retrieved from the spectral AOD following the constrained linear inversion method (King, 1982) by numerical inversion of the integral equation,

$\tau_{p \lambda}(\lambda)=\int_{0}^{\infty} \int_{0}^{\infty} \pi r^{2} Q_{\mathrm{ext}}(r, \lambda, m) n(r, z) d z d r$

where $n(r, z) d r$ is the aerosol number density at altitude $z$ in an infinitesimal radius interval $\mathrm{dr}$ centered around $r, m$ is 

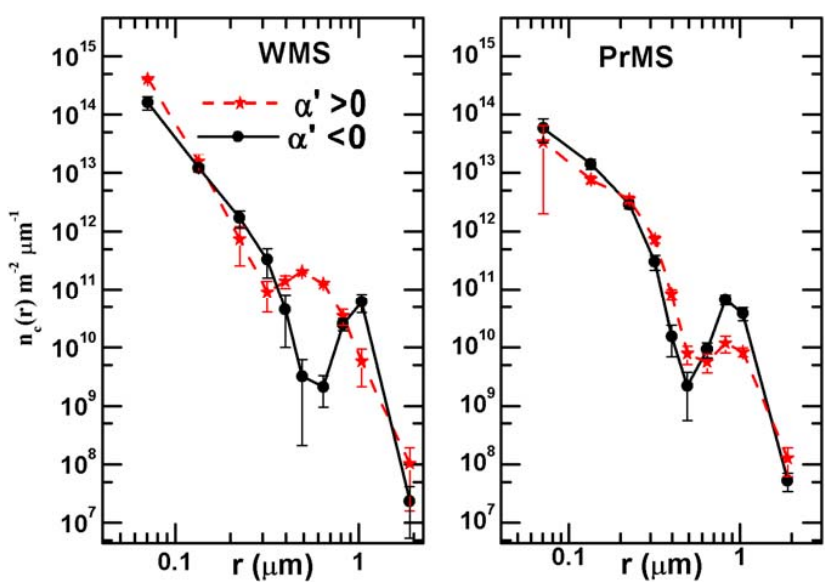

Fig. 9. Typical, retrieved columnar size distributions during winter (left panel) and pre-monsoon season (right panel) during the periods of contrasting spectral curvatures (positive and negative values of $\left.\alpha^{\prime}\right)$.

the complex refractive index of the particle, $\lambda$ is the wavelength of the radiation and $Q_{\text {ext }}(r, \lambda, m)$, the Mie extinction efficiency parameter. Assuming a columnar size distribution, as an equivalent size distribution of the aerosols in the vertical column which, while remaining height invariant, produces the same AOD spectrum as the measured at ground, and expressed as $n_{\mathrm{c}}(r)=\int_{0}^{\infty} n(r, z) d z$, Eq. (6) can be reduced to a set of simultaneous equations which are to be solved numerically.

Several methods are available in the literature for inferring the CSD from AOD measurements at multiple wavelengths; these include the look up table method (Box and Lo, 1976; Box et al., 1981), the constrained linear inversion technique (King et al., 1978; King, 1982; Saha and Moorthy, 2004) and the randomized minimization search technique (RMST) (Anderson et al., 2000). In the present study, the constrained linear inversion technique was followed. The application of this method to derive columnar size distributions from spectral AODs have been described by King et al. (1978) and King (1982), and its application to the MWR data have been explained by Moorthy et al. (1991), Saha et al. (2005), Beegum et al. (2009) and Gogoi et al. (2009). Following these, the spectral AOD data have been inverted to obtain the CSDs for all the seven years. In doing so, the wavelength-dependent refractive index of aerosols (for a polluted marine environment) has been used as given by Lubin et al. (2002), in view of the mixed nature (continental and marine, natural and anthropogenic) of the aerosols over the location. The lower and upper radii limits of $0.05 \mu \mathrm{m}$ to $5 \mu \mathrm{m}$ for the particles were considered (in view of the span of wavelengths used in the MWR, Saha and Moorthy, 2004). In general, a convergence was obtained after four to six iterations and for reasonably low values of the relative Lagrange multiplier, $\gamma_{\text {rel }}(<1.0)$.

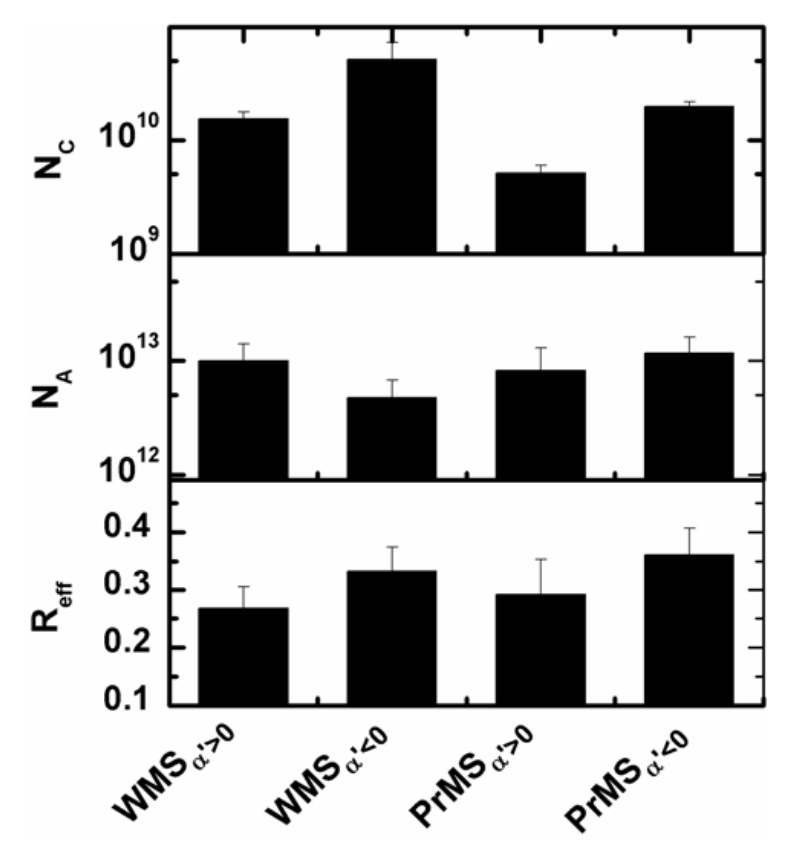

Fig. 10. The mean pattern for effective radius $R_{\text {eff }}$, coarse mode concentration $N_{\mathrm{C}}$ and accumulation mode concentration $N_{\mathrm{A}}$, estimated from the retrieved size distributions during the periods of contrasting spectral curvatures.

\subsection{CSDs at Port Blair}

Columnar size distributions, retrieved from individual day AOD spectrum, were averaged, after segregating in terms of the spectral curvatures, separately for each of the seasons. The resulting average size distributions are shown in the Fig. 9 for WMS (left panel) and PrMS (right panel).

It is clear from the figure (Fig. 9, left panel) that during winter season, as $\alpha^{\prime}$ changes from positive to negative, the CSD shows distinct transition from a power-law unimodal $(\mathrm{PL}+\mathrm{UM})$ distribution (red) to a bimodal (BM) distribution (black) with a prominent coarse particle mode occurring at higher radii $(\sim 0.8$ to $1 \mu \mathrm{m})$. In the PL+UM distribution, the primary mode is not explicitly depicted, but rather follows an inverse power-law type of distribution for the small particle regime $(r<\sim 0.3 \mu \mathrm{m})$ followed by a mode indicated at around $0.5 \mu \mathrm{m}$, leading to fine/accumulation mode dominance. In the second case (BM), though the primary mode is not explicit, the slanting nature of the distribution for $r<0.2 \mu \mathrm{m}$ indicates the possible occurrence of a mode at a radius below the lower limit considered in the inversion, and the secondary mode is occurring $\sim 1 \mu \mathrm{m}$ leading to a relative coarse mode abundance. Modes of the distributions have been confirmed using analytical parameterizations. During PrMS, even though BM size distribution occurred for both the cases, the coarse mode abundance is significantly higher when the spectral curvatures were concave. This is evident from the average six-fold increase in the amplitudes of the secondary mode (at $1.0 \mu \mathrm{m})$ in the case of concave spectral 
curvature in comparison with the other. In addition, the primary mode shifted more towards the shorter radius for the cases when the spectral curvatures were convex. Thus, it emerges that the convex spectral curvatures of AOD arise due to the abundance of accumulation mode aerosols in the vertical column. In order to further substantiate the above, the effective radius, $R_{\text {eff }}$, concentration of coarse mode aerosols $\left(N_{\mathrm{C}}\right)$ and the concentration of accumulation mode aerosols $\left(N_{\mathrm{A}}\right)$ were estimated from each of the inverted CSDs. The seasonal variations of these parameters in Fig. 10 clearly reveal that as the spectral curvature changes from convex to concave, there is a steady increase in the $R_{\text {eff }}$, decrease in $N_{\mathrm{A}}$ and an increase in $N_{\mathrm{C}}$ for winter. Even though the pattern is similar in PrMS, the increase in $N_{\mathrm{C}}$ is quite significant as $\alpha^{\prime}$ changes from positive to negative, and this can negate the effect of the very weak increase in the values of $N_{\mathrm{A}}$ during the season. In the backdrop of the above observations, a comparison of the physical parameters estimated from the inverted CSDs is made with the near-surface mass size distributions measured concurrently using the QCM Impactor. Though the near-surface aerosols (those in the well mixed atmospheric boundary layer) need not be fully representative of that in the vertical column, due to possible presence of aerosols layers of different types (for e.g. Satheesh et al., 2008), they contribute significantly to the columnar abundance and also to the optical depth.

\subsection{Mass size distributions of near-surface Aerosols}

With a view to comparing the size distributions of nearsurface aerosols deduced from the QCM measurements with the CSDs derived from the spectral AODs, the QCM-derived mass-size distributions have been segregated based on the spectral curvature (whether positive or negative) of the AOD and averaged. The resulting climatological average MSDs for the cases of both positive and negative values of $\alpha^{\prime}$ are given respectively in the top and bottom panels of the Fig. 11 . As the QCM measurements were restricted to periods of $\mathrm{RH}<75 \%$, in view of the affinity of quartz to changes in $\mathrm{RH}$ at high RH values, the QCM data have been obtained only for the period from December to April.

It is interesting to note the presence of a strong accumulation mode at the particle diameter $<0.5 \mu \mathrm{m}$ during WMS and PrMS seasons when spectral curvatures in AOD were convex $\left(\alpha^{\prime}>0\right)$. A weaker coarse mode $(>2 \mu \mathrm{m})$ is also indicated, most probably associated with the ever-present seaspray aerosols in the (marine) atmospheric boundary layer of the island. However, as $\alpha^{\prime}$ becomes negative, there is significant enhancement in the coarse mode concentration at $\sim 6 \mu \mathrm{m}$ diameter with amplitude of $\sim 23 \mu \mathrm{g} \mathrm{m}^{-3}$. Along with this, the accumulation mode becomes less conspicuous. These observations are in general conformity with the inferences deduced from the CSDs retrieved from the AOD spectra. This also suggests the prevalence of a general homogeneity in the microphysical properties of aerosols in ABL and those in the

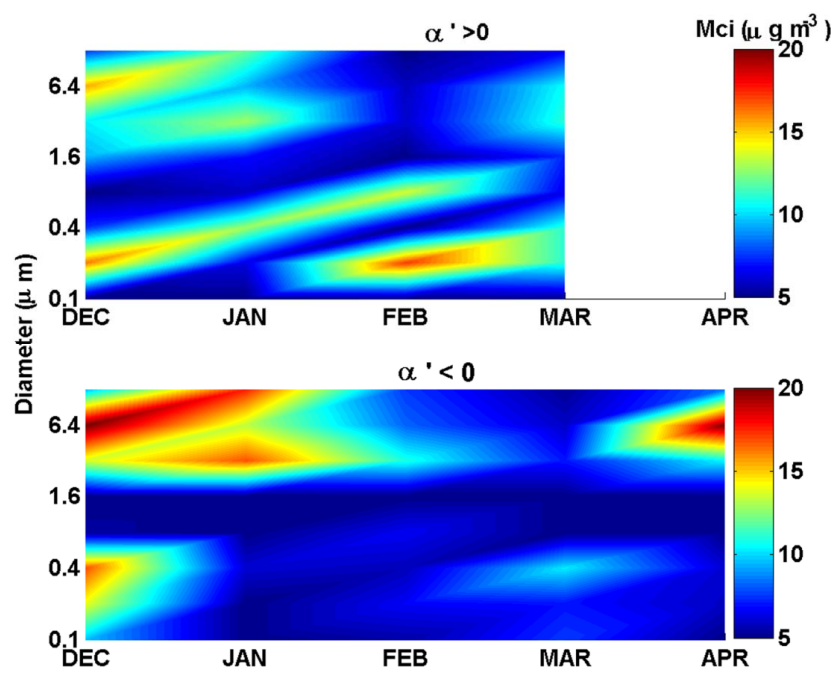

Fig. 11. Climatological mean pattern of near-surface mass size distributions from Quartz Crystal Microbalance for the cases of contrasting spectral curvatures during the study period.

column. It may be recalled that based on recent ship-borne measurements from the Eastern BoB during winter season, Moorthy et al. (2010) have reported the prevalence of homogenous vertical distribution of aerosols. This suggests that the aerosols in the ABL are representative of the aerosols in the vertical column. With a view to examining this, even when the size distributions showed intra-seasonal changes, the association between the size distribution parameters derived from QCM and $\alpha^{\prime}$ are examined in the scatter plots in Fig. 12. It is seen that both $R_{\mathrm{eff}}$ and $M_{\mathrm{C}}$ (coarse mode mass concentration) depict an inverse relationship with $\alpha^{\prime}$. Even though the correlation coefficient is weak, (slightly less than 0.5 ), it is statistically significant. Similarly, the accumulation mode mass concentration $M_{\mathrm{A}}$ is positively correlated with $\alpha^{\prime}$, suggesting the dominance of these small particles in producing a convex AOD spectrum.

\section{Discussion}

The inferences drawn from the above observations point towards the intra-seasonal fluctuations of microphysical properties of aerosols at PBR, associated with the similar variabilities in the advection of different aerosol types associated with distinct source regions. With a view to further verifying the above, and to investigate the role of long-range transport towards the observed pattern, 5-day isentropic airmass back trajectories (using HYSPLIT) arriving at the station at the three height levels of $500 \mathrm{~m}$ (within the ABL), $1500 \mathrm{~m}$ (above the $\mathrm{ABL}$ ) and $3500 \mathrm{~m}$ (in the free troposphere) have been examined during the period of MWR measurements. These have been clustered (Owen, 2003; Beegum et al., 2009) for each of the seasons, separately for the two distinct spectral curvatures (of AOD) by clubbing the trajectories at all 

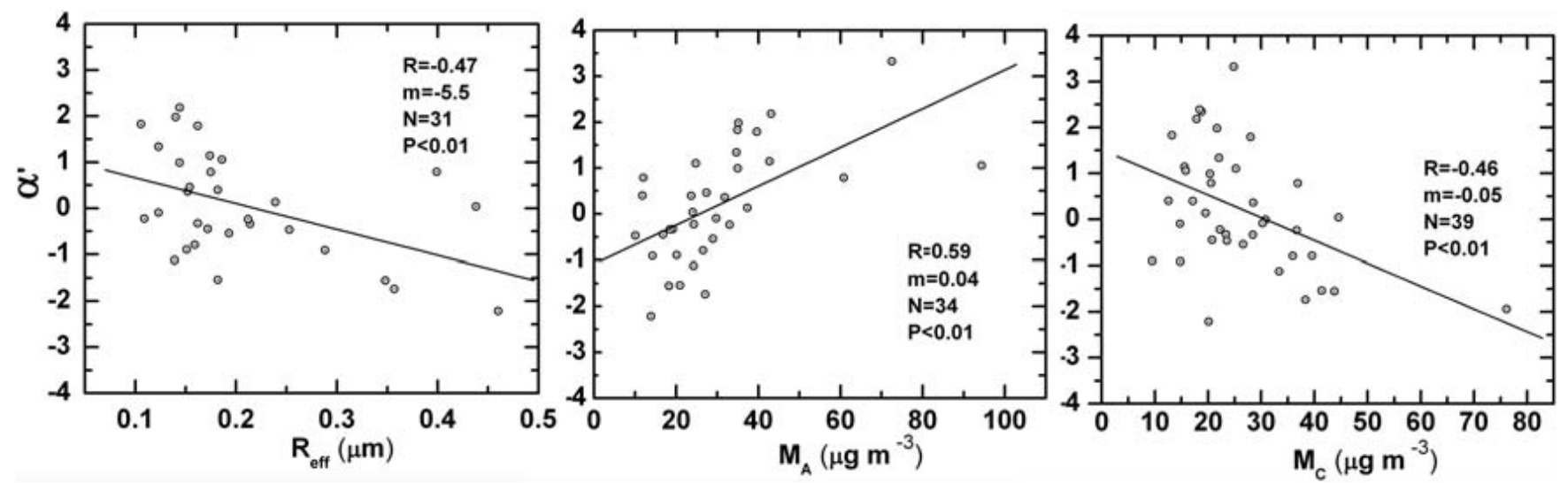

Fig. 12. The scatter plots showing the association of $\alpha^{\prime}$ with the size distribution parameters (estimated from QCM measurements of mass size distributions); (a) the effective radius $R_{\mathrm{eff}}$, (b) accumulation mode mass concentration $M_{\mathrm{A}}$, and (c) coarse mode mass concentration $M_{\mathrm{C}}$.
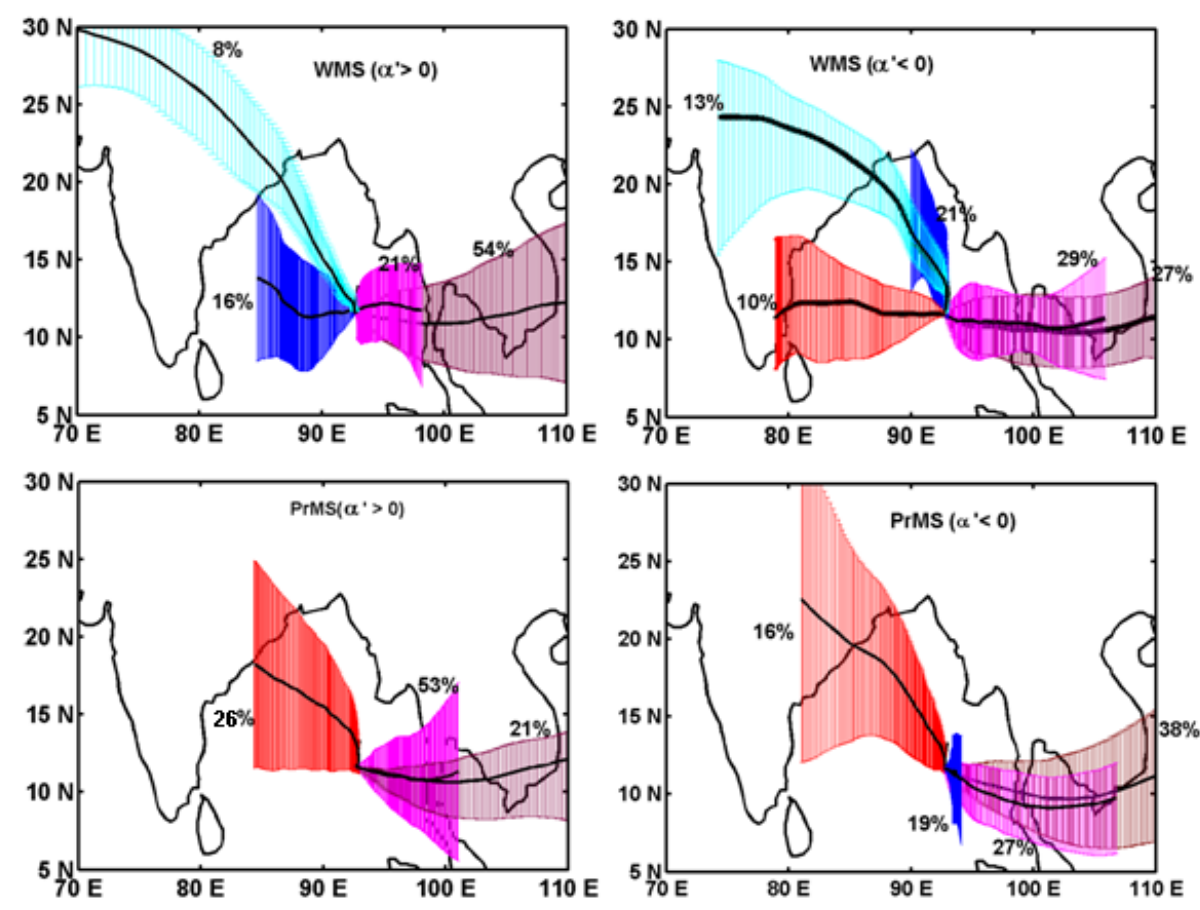

Fig. 13. The trajectory clusters arriving at Port Blair for WMS and PrMS for the cases of contrasting spectral curvatures.

the three height levels together, and the resulting patterns are shown in Fig. 13. It is evident that the trajectories are mainly either from the east (East Asia) or from the west (Indian subcontinent), even though the regions of overpass varied as we go back in time. As such, the trajectories have been clustered into 4 or 5 groups based on the regions of traverse and the length of the trajectories (back in time), as shown in Fig. 13. It is clear from the figure that during WMS, and when the spectral curvatures are convex, the trajectories from East Asia dominated with a percentage contribution of $\sim 75 \%$, while during the rest of the period the clusters are either from the oceanic regions having proximity to the eastern coastal India or from the Indian subcontinent. On the other hand, during the same season when the spectral curvatures are concave, the contribution from the East Asian region decreases significantly (decrease of $\sim 25 \%$ of the total) and the Indian landmass contributes as much as $45 \%$.

During PrMS also, the East Asian region contributes $\sim 75 \%$ to the total trajectory clusters when the spectral curvatures are convex, the remaining being contributed by the cluster originating from the eastern coastal India. As the spectral curvature tends to concave, an $11 \%$ decrease in the East Asian trajectories has been observed and a new cluster of 

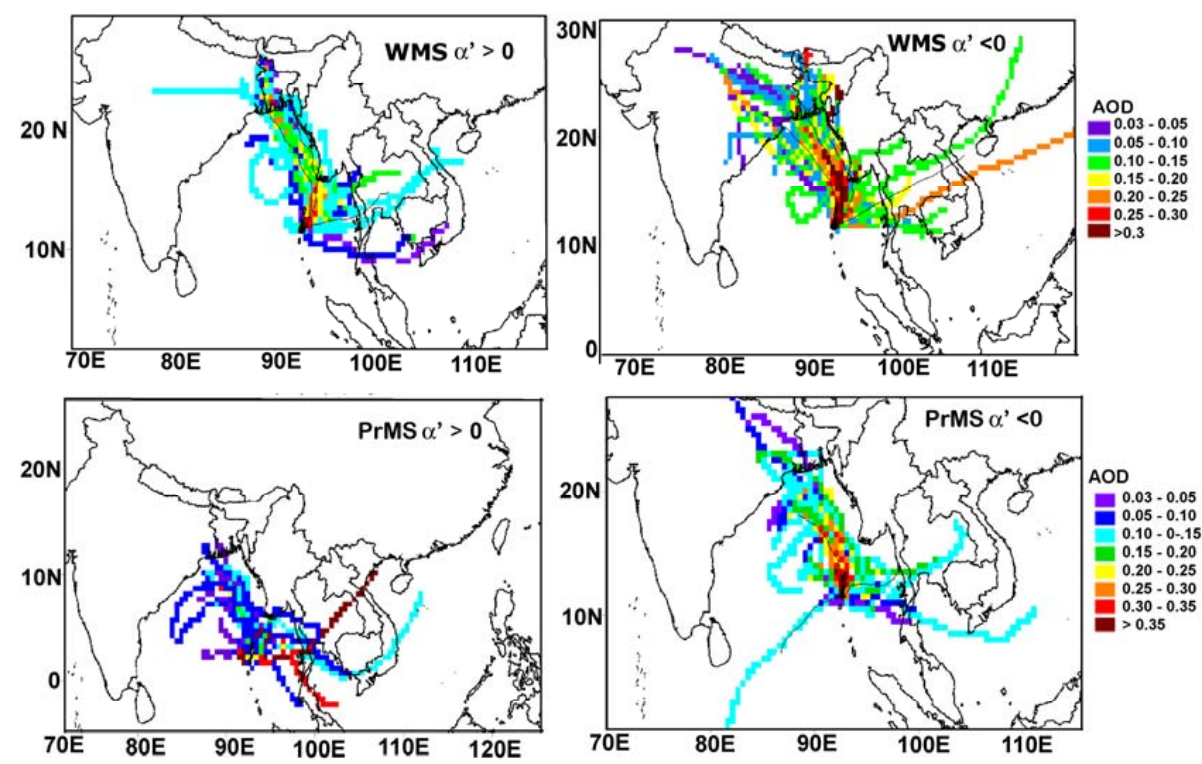

Fig. 14. The concentration weighted trajectory map at Port Blair at a height level of $1500 \mathrm{~m}$ during WMS and PrMS separately when the spectral curvatures are convex and concave.

local origin confined to the oceanic region (most probably sea-salt aerosols) is found to contribute $\sim 20 \%$ of the total.

It is interesting to note that, even though a relative decrease in the percentage contribution of the trajectories from the East Asia and a simultaneous increase in the percentage from the Indian subcontinent occurs as the spectral curvatures change from convex to concave types, the trajectories from the East Asian continental locations still remain $>50 \%$ of the total for both seasons. This hints towards the limitation of the simple trajectory clustering in identifying the potential sources of advection. As such, concentration weighted trajectory (CWT) analysis has been carried out for both the stations at different height levels.

\section{CWT analysis and potential source regions}

The advantage of the concentration weighted trajectory analysis (CWT) over the simple trajectory calculation is that it can quantify the regional contribution of each of advection pathways towards the measured aerosol parameters (either mass concentrations or column AOD). It would provide the spatial pattern of the potential sources of aerosols arriving at a receptor location (Seibert et al., 1994; Hsu et al., 2003; Vinoj et al., 2010). Here, the weights have been given to each of the trajectories arriving at the receptor site on the basis of the mean value of the measured aerosol parameter (AOD in this case). Hence, each grid point gets a weighted value obtained by averaging the data (AOD) measured at the receptor site as the associated trajectory crosses the grid point $(i, j)$ as

$C_{i j}=\frac{1}{\sum_{l=1}^{M} \tau_{i j l}} \sum C_{1} \tau_{i j l}$, where $C_{i j}$ is the average weighted AOD in the grid cell $(i, j)$, $M$ is the total number of trajectories, $l$ is the trajectory index, $C_{1}$ is the measured AOD at the receptor location (here Port Blair) associated with the trajectory $l$, and $\tau_{i j l}$ is the residence time of the trajectory $l$ in grid cell $(i, j)$. The weighted AOD values at each grid thus obtained represent the AOD that can be expected at the receptor site, at any time, if the trajectory were passed through the spatial grid.

The CWT analysis has been carried out by grouping the days separately in terms of their spectral curvatures (whether $\alpha^{\prime}$ is positive or negative) at three height levels. The CWT pattern at $1500 \mathrm{~m}$ (above MABL), as a representative, are shown in Fig. 14; the top left panel clearly reveals that during WMS, when positive values of $\alpha^{\prime}$ are observed, more than $90 \%$ of the trajectories are from the East/Northeast Asian continental locations. Among these, the potential source regions are identified over Bangladesh and Myanmar with source contribution of $\sim 0.2$. Even though a few trajectories were confined to Bay of Bengal and Indian subcontinent, the source contribution remains low $(\sim 0.05)$. Based on the shipborne measurements from the Bay of Bengal during winter season, Moorthy et al. (2010) have reported the prevalence of high fine/accumulation mode aerosol concentrations (well within the boundary layer as well as in the vertical column) and it is found that the advection from the East Asian continental locations contribute significantly to the observed pattern. As the values of $\alpha^{\prime}$ change to negative, the cluster of trajectories from the Indian subcontinent assumes dominance over the East Asian trajectories. The source contribution by these trajectories remained as high as $\sim 0.3$. Even though significant advection $(\sim 0.1)$ occurred from the East Asian locations, the effect of this has been rendered low by the 
extremely high source contribution by the trajectories from the Indian mainland and the size distributions of the aerosol show higher abundance of (natural) coarse mode particles. This is confirmed again from the CWT pattern during PrMS (shown in Fig. 14 bottom panels). The high source contribution due to the East Asian region contributes significantly to the convex type of spectral curvatures. The East Asian region comprises of continental locations of south China, Mongolia, Korea, etc., where the anthropogenic aerosol concentrations were reported to be very high (e.g. Hsu et al., 2007; Sahu et al., 2009). However, as the source contribution from the Indian mainland increases from $\sim 0.05$ to as high as 0.30 , the spectral curvature of AOD changes to concave (bottom right panel of Fig. 14).

Thus, CWT analysis revealed that the strength of advection varies intra-seasonally over Port Blair and it in turn causes associated changes in the columnar aerosol size distribution too. These observations unequivocally showed that the advection of significant amounts of coarse mode aerosols from the Indian mainland contributes significantly to the coarse mode in the columnar size distribution and leads to concave spectral curvature at PBR, while the accumulation mode aerosols advected from the East Asian regions are responsible for the convex spectral curvatures. In other words, the increased advection from the Indian mainland reverses the columnar size distribution from an accumulation modedominated one to a bimodal distribution with a strong coarse mode dominance (contributed by natural aerosols).

In this context, it is also interesting to note that, synthesizing the optical, chemical and physical properties of aerosols measured over the BoB during the ICARB 2006, Nair et al. (2010) have reported higher anthropogenic fraction to the AOD over the southern BoB compared to the northern BoB, where advection from the Indian mainland across the Indo Gangetic Plain dominated. Based on chemical analysis of aerosols and solubility of iron (Fe), Kumar et al. (2010) have reported that the outflow from the Indo-Gangetic Plain to the north $\mathrm{BoB}$ resulted in higher abundance of aerosol Fe (iron, which has undergone chemical processing by dust aerosols), which in turn indicated the increased amount of advected mineral dust. In contrast, over the southern $\mathrm{BoB}$, where the outflow was from the South-East Asia, enhanced fractional solubility of Fe, associated with the lower abundance of dust and dominance of combustion sources (biomass burning and fossil-fuel), was observed. This lends further support to our inferences.

\section{Conclusions}

Inferences on the climatology of aerosol optical depth, its spectral dependence and size distributions of aerosols near the surface have been made, for the first time, with the help of long-term ( $\sim 7$ years), concurrent measurements from the island station Port Blair, in the far eastern Bay of Bengal.
Changes in the microphysical properties of aerosols associated with the changes in the source impacts caused by changes in the advection pattern are delineated, and the regional source contributions are apportioned. The major findings are:

1. AODs were found to vary from 0.15 to 0.4 at $500 \mathrm{~nm}$ with strong seasonal and weaker, yet significant, interannual variations. The climatology of the monthly mean spectral AOD revealed a continuous increase from January to reach a peak value of $\sim 0.4$ in March and thereafter a decrease towards May.

2. Significant curvatures were observed in the relationship between $\ln \tau_{p \lambda}$ versus $\ln \lambda$, with intra-seasonal fluctuations in the derivative of the Angstrom wavelength exponent $\left(\alpha^{\prime}\right)$ where $\alpha^{\prime}$ is found to vary between highly positive and negative values in short time scales, even within a month, and the positive values of $\alpha^{\prime}$ are closely associated with easterlies and the negative values with westerlies.

3. The inverted columnar size distributions were also found to vary intra-seasonally between the powerlaw unimodal/bimodal distribution, with significant fine/accumulation mode aerosols when $\alpha^{\prime}>0$ (convex spectral curvature) and a bimodal distribution with comparatively higher amplitude of the secondary mode when $\alpha^{\prime}<0$ (concave spectral curvature). The retrieved parameters from the columnar size distributions were in conjunction with the above. As the spectral curvature changes from convex to concave, there is a steady increase in the effective radius, decrease in accumulation mode number concentration and an increase in coarse mode number concentration for winter.

4. Similar periodic variations in the size spectrum were also observed in the near-surface measurements of mass size distributions, which in turn confirm the intraseasonal periodicities in the microphysical properties of aerosols at the measurement site.

5. The potential advection pathways have been identified by the trajectory cluster analysis and the concentration weighted trajectory analysis (CWT). It has been observed that the highest potential source for anthropogenic aerosols at Port Blair is East Asia when the spectral curvatures were convex (positive values of the derivative of the Angstrom exponent, $\alpha^{\prime}$ ), whereas when the spectral curvatures were concave, the potential source of advection was from the Indian subcontinent. While the advected aerosols from the Indian subcontinent lead to natural aerosol dominance, those from the East Asian regions result in anthropogenic aerosol dominance at the receptor location, Port Blair. 
Acknowledgements. The work is carried out as a part of the Aerosol Radiative Forcing over India (ARFI) project of ISRO-GBP. The institutional and infrastructure support extended by the ISTRAC ground station is gratefully acknowledged. We also acknowledge the NOAA Air resources Laboratory for the provision of the HYSPLIT transport and dispersion model and READY website (http: //www.arl.noaa.gov/ready.html).

Topical Editor P. M. Ruti thanks D. Kaskaoutis and another anonymous referee for their help in evaluating this paper.

\section{References}

Anderson, J., Brogniez, C., Cazier, L., Saxena, V. R., Lenoble, J., and McCormick, M. P.: Characterization of aerosols from simulated SAGE III measurements applying two retrieval techniques, J. Geophys Res., 105, 2013-2027, 2000.

Andreae, M. O.: World Survey of Climatology, Future Climates of the World, edited by: Henderson-Sellers, A., Elsevier, New York, 16, 341-392, 1995.

Asnani, G. C.: Tropical Meteorology Vol.1 and Vol.2, Indian Institute of Tropical Meteorology, Pashan, Pune, 1012 pp., 1993.

Babu, S. S., Gogoi, M. M., Kumar, V. H. A., Nair, V. S., and Moorthy, K. K.: Radiative properties of Bay of Bengal aerosols: Spatial distinctiveness and source impacts, J. Geophys. Res., 117, D06213, doi:10.1029/2011JD017355, 2012.

Beegum, S. N., Moorthy, K. K., Nair, V. S., Babu, S. S., Satheesh, S. K., Vinoj, V., Reddy, R. R., Gopal, K. R., Badarinath, K. V. S., Niranjan, K., Pandey, S. K., Behera, M., Jeyaram, A., Bhuyan, P. K., Gogoi, M. M., Singh, S., Pant, P., Dumka, U. C., Kant, Y., Kuniyal, J. C., and Singh, D.: Characteristics of spectral aerosol optical depths over India during ICARB, J. Ear. Syst. Sci., 117, 303-313, 2008.

Beegum, S. N., Moorthy, K. K., and Babu, S. S.: Aerosol microphysics over a tropical coastal station inferred from the spectral dependence of Angstrom wavelength exponent and inversion of spectral aerosol optical depths, J. Atmos. Sol. Terr. Phys., 71, 1846-1857, 2009.

Box, M. A. and Lo, S. Y.: Approximate determination of aerosol size distributions, J. Appl. Meteorol., 15, 1068-1076, 1976.

Box, G. P., Box, M. A., and Deepak, A.: On the spectral sensitivity of the approximate method for retrieving aerosol size distributions from multispectral solar extinction measurements, J. Appl. Meteorol., 20, 944-948, 1981.

Chung, C. E., Ramanathan, V., Kim, D., and Podgomy, I.: Global anthropogenic aerosol direct forcing derived from satellite and ground-based observations, J. Geophys. Res., 110, D24207, doi:10.1029/2005JD006356, 2005.

Eck, T. F., Holben, B. N., Reid, J. S., Dubovic, O., Smirnov, A., O'Neill, N. T., Slutsker, I., and Kinne, S.: Wavelength dependence of the optical depth of biomass burning, urban, and desert dust aerosols, J. Geophys. Res., 104, 31333-31349, 1999.

Eck, T. F., Holben, B. N., Dubovic, O., Smirnov, A., Slutsker, I., Lobert, J. M., and Ramanathan, V.: Column-integrated aerosol optical properties over the Maldives during the northeast monsoon for 1998-2000, J. Geophys. Res., 106, 28555-28566, 2001.

Eck, T. F., Holben, B. N., Dubovic, O., Smirnov, A., Goloub, P., Chen, H. B., Chatenet, B., Gomes, L., Zhang, X. Y., Tsay, S. C., Ji, Q., Giles, D., and Slutsker, I.: Columnar aerosol optical properties at AERONET sites in Central Eastern Asia and aerosol transport to the Tropical Mid-Pacific, J. Geophys. Res., 110, D06202, doi:10.1029/2004JD005274, 2005.

El-Metwally, M., Alfaro, S. C., Wahab, M. A., and Chatenet, B.: Aerosol characteristics over urban Cairo: Seasonal variations as retrieved from Sun photometer measurements, J. Geophys. Res., 113, D14219, doi:10.1029/2008JD009834, 2008.

Gobbi, G. P., Kaufman, Y. J., Koren, I., and Eck, T. F.: Classification of aerosol properties derived from AERONET direct sun data, Atmos. Chem. Phys., 7, 453-458, doi:10.5194/acp-7-453-2007, 2007.

Gogoi, M. M., Moorthy, K. K., Babu, S. S., and Bhuyan, P. K.: Climatology of columnar aerosol properties and the influence of synoptic conditions: First-time results from the northeastern region of India, J. Geophys. Res., 114, D08202, doi:10.1029/2008JD010765, 2009.

Holben, B. N., Eck, T. F., and Fraser, R. S.: Temporal and spatial variability of aerosol optical depth in the Sahel region in relation to vegetation remote sensing, Int. J. Rem. Sen., 12, 1147-1163, 1991.

Hsu, Y. K., Holsen, T. M., and Hopke, P. K.: Comparison of hybrid receptor models to locate PCB sources in Chicago, Atmos. Environ., 37, 545-562, 2003.

Hsu, S. C., Liu, S. C., Kao, S. J., Jeng, W. L., Huang, Y. T., Tseng, C. M., Tsai, F., Tu, J. Y., and Yang, Y.: Water soluble species in the marine aerosol from the northern South China Sea: High chloride depletion related to air pollution, J. Geophys. Res., 112, D19304, doi:10.1029/2007JD008844, 2007.

Huebert, B. J., Bates, T., Russell, P. B., Shi, G., Jim, Y. J., Kawamura, K., Carmichael, G., and Nakajima, T.: An overview of ACE-Asia: Strategies for quantifying the relationships between Asian aerosols and their climatic impacts, J. Geophys. Res., 108, 8633, doi:10.1029/2003JD003550, 2003.

Kamra, A. K., Murugavel, P., Pawar, S. D., and Gopalakrishnan, V.: Background aerosol concentration derived from the atmospheric electric conductivity measurements made over the Indian ocean during INDOEX, J. Geophys. Res., 106, 28643-28651, 2001.

Kaskaoutis, D. G. and Kambezidis, H. D.: Investigation on the wavelength dependence of the aerosols in the Athens area, Q. J. Roy. Meteorol. Soc., 132, 2217-2234, 2006.

Kaskaoutis, D. G., Kambezidis, H. D., Adamopoulos, A. D., and Kssomenos, P. A.: On the characterization of aerosols using the Angstrom exponent in Athens area, J. Atmos. Sol. Terr. Phys., 68, 2147-2163, 2006.

Kaskaoutis, D. G., Kambezidis, H. D., Hatzianastassiou, N., Kosmopoulos, P. G., and Badarinath, K. V. S.: Aerosol climatology: dependence of the Angstrom exponent on wavelength over four AERONET sites, Atmos. Chem. Phys. Discuss., 7, 7347-7397, doi:10.5194/acpd-7-7347-2007, 2007.

Kaskaoutis, D. G., Kalapureddy, M. C. R., Krishna Moorthy, K., Devara, P. C. S., Nastos, P. T., Kosmopoulos, P. G., and Kambezidis, H. D.: Heterogeneity in pre-monsoon aerosol types over the Arabian Sea deduced from ship-borne measurements of spectral AODs, Atmos. Chem. Phys., 10, 4893-4908, doi:10.5194/acp-10-4893-2010, 2010.

Kaskaoutis, D. G., Kumar Kharol, S., Sinha, P. R., Singh, R. P., Kambezidis, H. D., Rani Sharma, A., and Badarinath, K. V. S.: Extremely large anthropogenic-aerosol contribution to total aerosol load over the Bay of Bengal during winter season, Atmos. Chem. Phys., 11, 7097-7117, doi:10.5194/acp-11-7097- 
2011, 2011.

Kaufman, Y. J., Setzer, A., Ward, D., Tanre, D., Holben, B. N., Menzel, P., Pereira, M. C., and Rasmussen, R.: Biomass Burning Airborne and Spaceborne Experiment in the Amazonas (BASE-A), J. Geophys. Res., 97, 14581-14599, 1992.

Kharol, S. K., Badarinath, K. V. S., Kaskaoutis, D. G., Sharma, A. R., and Gharai, B.: Influence of continental advection on aerosol characteristics over Bay of Bengal $(\mathrm{BoB})$ in winter: results from W-ICARB cruise experiment, Ann. Geophys., 29, 1423-1438, doi:10.5194/angeo-29-1423-2011, 2011.

King, M. D.: Sensitivity of constrained linear inversion to the selection of Lagrange multiplier, J. Atmos. Sci., 28, 245-258, 1982.

King, M. D. and Byrne, D. M.: A method for inferring total ozone content from spectral variation of total optical depth obtained with a solar radiometer, J. Atmos. Sci., 33, 2242-2251, 1976.

King, M. D., Byrne, D. M., Herman, B. M., and Reagan, J. A.: Aerosol size distributions obtained by inversion of spectral optical depth measurements, J. Atmos. Sci., 35, 2153-2167, 1978.

Kompalli, S. K., Babu, S. S., and Moorthy, K. K.: Inter-Comparison of aerosol optical depth from Multi-Wavelength solar radiometer with other radiometric measurements, Ind. J. Rad. Spac. Phys., 39, 364-371, 2010.

Krishna Moorthy, K., Suresh Babu, S., and Satheesh, S. K.: Temporal heterogeneity in aerosol characteristics and the resulting radiative impact at a tropical coastal station - Part 1: Microphysical and optical properties, Ann. Geophys., 25, 2293-2308, doi:10.5194/angeo-25-2293-2007, 2007.

Kumar, A., Sarin, M. M., and Srinivas, B.: Aerosol iron solubility over Bay of Bengal: Role of anthropogenic sources and chemical processing, Mar. Chemist., 121, 167-175, 2010.

Lau, K. M., Kim, M. K., and Kim, K. M.: Asian summer monsoon anomalies induced by aerosol direct forcing: The role of the Tibetan Plateau, Clim. Dynam., 26, 855-864, 2006.

Li, F. and Ramanathan, V.: Winter to summer monsoon variation of aerosol optical depth over the tropical Indian Ocean, J. Geophys. Res., 107, 4284, doi:10.1029/2001JD000949, 2002.

Lubin, D., Satheesh, S. K., McFarquar, G., and Heymsfield, A. J.: Longwave radiative forcing of Indian Ocean tropospheric aerosol, J. Geophys. Res., 107, 8004, doi:10.1029/2001jd001183, 2002.

Menon, S., Hansen, J., Nazarenko, L., and Luo, Y.: Climate Effects of Black Carbon Aerosols in China and India, Science, 297, 2250-2252, 2002.

Moorthy, K. K. and Babu, S. S.: Aerosol black carbon over Bay of Bengal observed from an island location, Port Blair: Temporal features and long-range transport, J. Geophys. Res., 111, D17205, doi:10.1029/2005JD006855, 2006.

Moorthy, K. K. and Saha, A.: Aerosol study during INDOEX: Observation of enhanced aerosol activity over the mid Arabian Sea during the northern winter, J. Atmos. Sol. Terr. Phys., 62, 65-72, 2000.

Moorthy, K. K. and Satheesh, S. K.: Characteristics of aerosols over a remote island, Minicoy in the Arabian Sea, optical properties and retrieved size characteristics, Q. J. Roy. Meteorol. Soc., 126, 81-109, 2000.

Moorthy, K. K., Nair, P. R., and Murthy, B. V. K.: Size distribution of coastal aerosols:effects of local sources and sinks, J. Appl. Meteorol., 30, 844-852, 1991.
Moorthy, K. K., Babu, S. S., and Satheesh, S. K.: Aerosol spectral optical depths over the Bay of Bengal: Role of transport, Geophys. Res. Lett., 30, 1249, doi:10.1029/2002GL016520, 2003.

Moorthy, K. K., Babu, S. S., and Satheesh, S. K.: Aerosol characteristics and radiative impacts over the Arabian Sea during the intermonsoon season: Results from ARMEX field campaign, J. Atmos. Sci., 62, 192-206, 2005.

Moorthy, K. K., Satheesh, S. K., Babu, S. S., and Dutt, C. B. S.: Integrated campaign for Aerosols gases and radiation budget, J. Ear. Syst. Sci., 117, S1, 243-262, 2008.

Moorthy, K. K., Nair, V. S., Babu, S. S., and Satheesh, S. K.: Spatial and vertical heterogeneities in aerosol properties over oceanic regions around India: Implications for radiative forcing, Q. J. Roy. Meteorol. Soc., 135, 2131-2145, 2009.

Moorthy, K. K., Beegum, S. N., Babu, S. S., Smirnov, A., John, S. R., Kumar, K. R., Narasimhulu, K., Dutt, C. B. S., and Nair, V. S.: Optical and physical characteristics of Bay of Bengal aerosols during W-ICARB: Spatial and vertical heterogeneities in the marine atmospheric boundary layer and in the vertical column, J. Geophys. Res., 115, D24213, doi:10.1029/2010JD014094, 2010.

Nair, V. S., Babu, S. S., and Moorthy, K. K.: Spatial distribution and spectral characteristics of aerosol single scattering albedo over the Bay of Bengal inferred from shipborne measurements, Geophys. Res. Lett., 35, L10806, doi:10.1029/2008GL033687, 2008.

Nair, V. S., Moorthy, K. K., and Babu, S. S.: Optical and Physical Properties of Atmospheric Aerosols over the Bay of Bengal during ICARB, J. Atmos. Sci., 66, 2640-2658, 2009.

Nair, V. S., Satheesh, S. K., Moorthy, K. K., Babu, S. S., Nair, P. R., and George, S. K.: Surprising observation of large anthropogenic aerosol fraction over the "near-pristine" southern Bay of Bengal: Climate implications, J. Geophys. Res., 115, D21201, doi:10.1029/2010JD013954, 2010.

O’Neill, N. T., Dubovic, O., and Eck, T. F.: Modified Angstrom exponent for the characterization of submicrometer aerosols, Appl. Optics, 40, 2368-2375, 2001a.

O’Neill, N. T., Eck, T. F., Holben, B. N., Smirnov, A., Dubovik, O., and Royer, A.: Bimodal size distribution in?uences on the variation of the Angstrom derivatives in spectral and optical depth space, J. Geophys. Res., 106, 9787-9806, 2001 b.

O’Neill, N. T., Eck, T. F., Holben, B. N., Smirnov, A., Royer, A., and Li, Z.: Optical properties of boreal forest fire smoke derived from Sun photometry, J. Geophys. Res., 107, D11, doi:10.1029/2001JD000877, 2002.

O’Neill, N. T., Eck, T. F., Smirnov, A., Holben, B. N., and Thulasiraman, S.: Spectral discrimination of coarse and fine mode optical depth, J. Geophys. Res., 108, 4559, doi:101029/2002JD002975, 2003.

Owen, R. C.: A Climatological study of Transport to the PICONARE site using Atmospheric backward Trajectories, Ph.D. thesis, Civil and environmental Engineering, Michigan technological University, 2003.

Pillai, P. S. and Moorthy, K. K.: Aerosol mass-size distributions at a tropical coastal environment: Response to mesoscale and synoptic processes, Atmos. Environ., 35, 4099-4112, 2001.

Prospero, J. M., Charlson, R. J., Mohnen, B., Jaenicke, R., Delany, A. C., Mayers, J., Zoller, W., and Rahn, K.: The atmospheric aerosol system - an overview, Rev. Geophys., 21, 1607-1629, 1983. 
Ramanathan, V., Crutzen, P., J., Lelieveld, J., Mitra, A. P., Althausen, D., Anderson, J., Andreae, M. O., Cantrell, W., Cass, G. R., Chung, C. E., Clarke, A. D., Coakley, J. A., Collins, W. D., Conant, W. C., Dulac, F., Heintzenberg, J., Heymsfield, A. J., Holben, B., Howell, S., Hudson, J., Jayaraman, A., Kiehl, J. T., Krishnamurti, T. N., Lubin, D., McFarquhar, G., Novakov, T., Ogren, J. A., Podgorny, I. A., Prather, K., Priestley, K., Prospero, J. M., Quinn, P. K., Rajeev, K., Rasch, P., Rupert, S., Sadourny, R., Satheesh, S. K., Shaw, G. E., Sheridan, P., and Valero, F. P. J.: Indian Ocean experiment: An integrated analysis of the climate forcing and effects of the great Indo-Asian haze, Geophys. Res., 106, 28371-28398, 2001.

Ramanathan, V., Chung, C., Kim, D., Bettge, T., Buja, L., Kiehl, J. T., Washington, W. M., Fu, Q., D. R. Sikka, D. R., and Wild, M.: Atmospheric brown clouds: Impacts on South Asian climate and hydrological cycle, Proc. Nat. Acc. Sci., 102, 5326-5333, 2005.

Reid, J. S., Eck, T. F., Christopher, S. A., Hobbs, P. V., and Holben, B. N.: Use of the Angstrom exponent to estimate the variability of optical and physical properties of ageing smoke particles in Brazil, J. Geophys. Res., 104, 27473-27489, 1999.

Saha, A. and Moorthy, K. K.: Impact of precipitation on aerosol spectral optical depth and retrieved size distributions: a case study, J. Appl. Meteorol., 43, 902-914, 2004.

Saha, A., Moorthy, K. K., and Niranjan, K.: Interannual Variations of Aerosol Optical Depth over Coastal India: Relation to Synoptic Meteorology, J. Appl. Meterol., 44, 1066-1077, 2005.

Sahu, L. K., Kondo, Y., Miyazaki, Y., Kuwata, M., Koike, M., Takegawa, N., Tanimoto, H. Matsueda, H., Yoon, S. C., and Kim, Y. J.: Anthropogenic aerosols observed in Asian continental outflow at Jeju Island, Korea, in spring 2005, J. Geophys. Res., 114, D03301, doi:10.1029/2008JD010306, 2009.

Satheesh, S. K. and Moorthy, K. K.: Aerosol characteristics over coastal regions of the Arabian Sea, Tellus, 49B, 417-428, 2000.

Satheesh, S. K. and Moorthy, K. K.: Radiative effects of natural aerosols: A review, Atmos. Environ., 39, 1765-1774, 2005.
Satheesh, S. K., Srinivasan, J., and Moorthy, K. K.: Spatial and temporal heterogeneity in aerosol properties and radiative forcing over Bay of Bengal: Sources and role of aerosol transport, J. Geophys. Res., 111, D08202, doi:10.1029/2005JD006374, 2006.

Satheesh, S. K., Moorthy, K. K., Babu, S. S., Vinoj, V., and Dutt, C. B. S.: Climate implications of large warming by elevated aerosols over India, Geophys. Res. Lett., 33, L20816, doi:10.1029/2008GL034944, 2008.

Schuster, G. L., Dubovik, O., and Holben, B. N.: Angstrom exponent and bimodal aerosol size distributions, J. Geophys. Res., 111, D07207, doi:10.1029/2005JD006328, 2006.

Seibert, P., Kromp-Kolb, H., Baltensperger, U., Jost, D. T., Schwikowski, M., Kasper, A., and Puxbaum, H.: Trajectory analysis of aerosol measurements at high Alpine sites. SPB Acad. Publ., The Hague, Netherlands, 689-693, 1994.

Srinivas, B., Sarin, M. M., and Sarma, V. V. S. S.: Atmospheric dry deposition of inorganic and organic nitrogen to the Bay of Bengal: Impact of continental outflow, Mar. Chem., 127, 170179, 2011.

Vinoj, V. and Satheesh, S. K.: Measurements of aerosol optical depth over Arabian Sea during summer monsoon season, Geophys. Res. Lett., 30, 1263, doi:10.1029/2002GL016664, 2003.

Vinoj, V., Babu, S. S., Satheesh, S. K., Moorthy, K. K., and Kaufman, Y. J.: Radiative forcing by aerosols over the Bay of Bengal region derived from shipborne, island-based, and satellite (Moderate-Resolution Imaging Spectroradiometer) observations, J. Geophys. Res., 109, D05203, doi:10.1029/2003JD004329, 2004.

Vinoj, V., Satheesh, S. K., and Moorthy, K. K.: Optical, radiative, and source characteristics of aerosols at Minicoy, a remote island in the southern Arabian Sea, J. Geophys. Res., 115, D01201, doi:10.1029/2009JD011810, 2010.

Westphal, D. and Toon, O.: Simulations of microphysical, radiative, and dynamical processes in a continental-scale forest fire smoke plume, J. Geophys. Res., 96, 22379-22400, 1991. 